\title{
Sebaceous carcinoma of the eyelid - different diagnostic times, different outcomes: case reports
}

\author{
Carcinoma de glândulas sebáceas palpebral - diferentes momentos de diagnósticos, \\ diferentes resultados cirúrgicos: relatos de casos
}

Lucas Monferrari Monteiro Vianna ${ }^{1}$, Angelino Julio Cariello ${ }^{1}$, Márcia Serva Lowen², Ana Estela Besteti Ponce Sant'Anna ${ }^{1}$, Ana Luisa Hofling-Lima ${ }^{3}$

\begin{abstract}
Sebaceous carcinoma of the eyelid is a very rare slow-growing tumor and is considered an aggressive eyelid neoplasm. It can reach mortality rate of about $6 \%$. Diagnosis is often delayed because of its ability to masquerade as other periocular lesions, both clinically and histologically. We present three cases of sebaceous carcinoma, with different surgical outcomes, showing the importance of early diagnosis.
\end{abstract}

Keywords: Sebaceous gland neoplasms/diagnosis; Sebaceous adenocarcinoma; Eyelid neoplasms/surgery; Reconstructive surgical procedures; Early diagnosis; Humans; Male; Female; Middle aged; Aged; Case reports

\section{RESUMO}

Carcinoma sebáceo é um tumor raro de crescimento lento considerado uma das mais agressivas neoplasias palpebrais. Pode alcançar taxa de mortalidade de aproximadamente $6 \%$. O diagnóstico tardio é comum devido a sua habilidade de se confundir com outras lesões perioculares tanto clinicamente quanto histologicamente. Relatamos três casos de carcinoma sebáceo da pálpebra com diferentes resultados cirúrgicos, enfatizando a importância do diagnóstico precoce.

Descritores: Neoplasias das glândulassebáceas/diagnóstico;Adenocarcinomasebáceo Neoplasias palpebrais/cirurgia; Procedimentos cirúrgicos reconstrutivos; Diagnóstico precoce; Humanos; Masculino; Feminino; Meia-idade; Idosos; Relatos de casos

\section{INTRODUCTION}

Sebaceous carcinoma (SC) of the eyelid is a rare slow-growing tumor that affects the elderly men and women ${ }^{(1)}$, arising from meibomian, Zeis or sebaceous glands in the caruncle, eyebrow or surrounding skin. SC accounts for approximately $0.2 \%$ to $0.8 \%$ of all eyelid tumors and $1.0 \%$ to $5.5 \%$ of all eyelid malignancies ${ }^{(2)}$.

Diagnosis is often delayed because of its ability to masquerade as other periocular lesions, both clinically (chronic blefaroconjunctivitis and recurrent chalazion) and histologically, mainly basal cell carcinoma (BCC) and squamous cell carcinoma (SCC)(3). The most common method of metastasis of eyelid SC is through the lymphatic channels to regional lymph nodes and it may reach mortality rate of $6 \%$ due to metastasis ${ }^{(3)}$. Conservative surgery may be tried for treatment of localized SC, however aggressive procedures are frequently performed due to delaying in the diagnosis ${ }^{(4,5)}$.

We present three cases of SC, with different surgical outcomes, showing the importance of early diagnosis.

\section{CASE REPORTS}

\section{CASE 1}

A 73 year-old woman presented with 1-year history of an elevated slow growing lesion in the left upper eyelid. She smoked for
35 years, and referred chronic solar exposure. On examination, a chalazion-like 5-mm nodular lesion with localized madarosis was noted on eyelid margin (Figure 1A). Eversion of the eyelid displayed real size of the lesion (7x9 $\mathrm{mm}$ ), involving approximately $50 \%$ of the tarsus (Figure 1B). No lymph nodes were detected. An incisional biopsy was performed and the histopathology revealed an SC infiltrating the tarsus. The patient underwent surgical excision with intraoperative frozen section. Three millimeters of healthyappearing tissue excision was enough to achieved tumor freemargins. Direct closure eyelid reconstruction was performed using Tenzel procedure ${ }^{(6)}$. The patient had good functional, anatomical and esthetic outcomes. The 15-day postoperative aspect is showed in figure 1C. At 12 months of follow-up, there was no evidence of recurrence or metastasis.

\section{Case 2}

A 58-year-old man developed a nodular lesion in the right upper eyelid with telangiectasia, local madarosis and ulcerated center (Figure 2A), clinically diagnosed and surgically treated as chalazion, two years ago. The patient had no information about previous histological analysis. No lymph nodes were found. He had systemic hypertension, tobacco use for 40 years and chronic solar exposure. Everting the tarsus, the lesion displayed greater proportions, com-
Submitted for publication: September 14, 2010

Accepted for publication: August 4, 2011

Study carried out at the Federal University of São Paulo - UNIFESP - São Paulo, SP, Brazil.

${ }^{1}$ Physician, Department of Ophthalmology, Universidade Federal de São Paulo - UNIFESP - São Paulo (SP), Brazil.

2 Physician, Department of Morphology, Universidade Federal de São Paulo - UNIFESP - São Paulo

(SP), Brazil.
${ }^{3}$ Professor, Department of Ophthalmology, Universidade Federal de São Paulo - UNIFESP - São Paulo Professor, Dep

(SP), Brazil.

The study was approved by the UNIFESP Ethical Committee (number 0819/11).
Funding: No specific financial support was available for this study.

Disclosure of potential conflicts of interest: L.M.M.Vianna, None; A.J.Cariello, None; M.S.Lowen, None; A.E.B.P.Sant'Anna, None; A.L.Hofling-Lima, None.

Correspondence address: Angelino Julio Cariello. Sadalla Amin Ghanem Eye Hospital. Rua Abdon Batista, 146 - Joinville (SC) - 89201-010 - Brazil - E-mail: angelino65@yahoo.com

Editorial Note: After completing the confidential analysis of the manuscript, $A B O$ discloses, with her agreement, the name Dr. Mariluza Sardinha as a reviewer. We thank her effort and expertise in participating in this process. 

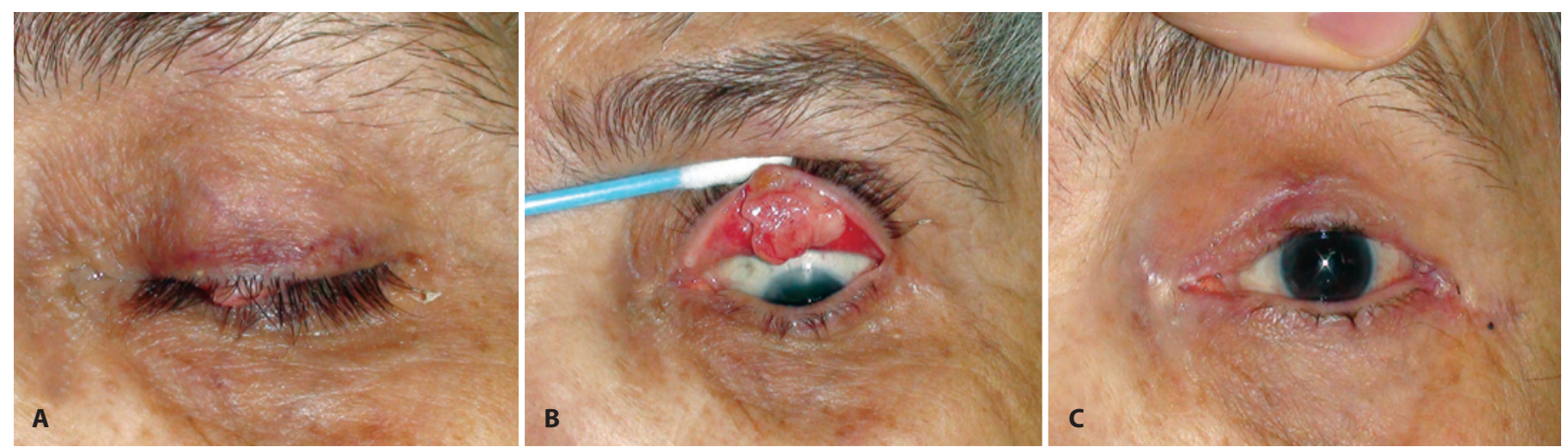

Figure 1. Patient 1: nodular lesion similar to a chalazion (A). The lesion involved approximately $50 \%$ of the tarsus (B). The postoperative aspect fifteen days after surgery (C).



retraction two months after reconstructive surgery.

promising more than $60 \%$ of the eyelid (Figure 2B). This patient underwent surgical excision of the visible tumor with $3-\mathrm{mm}$ of healthy-appearing margin in all directions. Intraoperative frozen analysis showed a superior compromising and an additional 2-mm resection was performed. Due to size of defect, it was necessary eyelid reconstruction using hard palate graft for the posterior lamella and sliding skin and muscle flap for the anterior lamella(6). Histological analysis confirmed the diagnosis of SC with clear margins. The patient evolved with upper eyelid retraction (Figure 2C) and a transient keratitis and has opted for no further surgical procedures. At one-year follow-up, there was no evidence of recurrence or metastasis.

\section{CAse 3}

A 71-year-old man was referred for chronic left eyelid and eye inflammation, beginning 5 years ago, diagnosed and treated as chronic blefaroconjunctivitis in several services. He presented to us complaining about progressive clinical worsening and low visual acuity for 1 year. He referred hypertension. His visual acuity was 20/25 OD and 20/50 OS. Left biomicroscopy evaluation showed a thickened and hyperemic superior eyelid, with viscous discharge and generalized cilia loss, associated with important and diffuse conjunctival hyperemia, superficial corneal opacity and $360^{\circ}$ limbal neovascularization (Figure 3A). No lymph nodes were detected. Multiple conjunctival map biopsies were performed including left upper and lower eyelid tarsus, superior and inferior cul-de-sac, four quadrant bulbar conjunctiva and the cornea epithelium. All specimens were compromised by SC with pagetoid spread. A magnetic resonance imaging showed signs of orbital fatty infiltration without bone involvement. Clinical systemic evaluation placed the patient in
T4NOM0 stage. Orbital exenteration was performed. Patient has been followed for 3 years, without signs of metastasis or recurrence.

\section{DISCUSSION}

These three patients with SC alert the importance of the early diagnosis in the final surgical outcome. The first case had a medium lesion diagnosed in an early time point. It allowed relatively simple surgical treatment with good functional and esthetic outcome. The misdiagnosis of chalazion in the case 2 compromised the surgical prognosis. It was necessary to perform a more aggressive surgery and the patient developed eyelid retraction, but it was still possible to preserve the visual function. In case 3, unfortunately, the misdiagnosis and late detection of the disease leaded the patient to a regrettable mutilating operation, recommended for this kind of pagetoid spread $^{(4)}$.

The diagnosis of SC can often be difficult both clinically and histopathologically ${ }^{(3,5)}$. As reminded case 2, any tissue surgical removed must always be sent to histopathological evaluation, even if it seems a benign lesion, as a chalazion ${ }^{(4)}$

The histopathology of SC is dominated by large anaplastic cells with open vesicular nuclei and prominent nucleoli set in foamy or frothy cytoplasm (lipid vacuoles). It is advisable to alert the pathologist to the possible diagnosis and ask for the preferred method of tissue handling ${ }^{(7)}$. When the histopathological result disagrees with the clinical suspicion, it is recommended thorough lamina revision ${ }^{(8)}$. This pathology is very rare ${ }^{(2)}$ and, probably, it is not uncommon that experienced pathologists are in front of their first SC case.

Blepharoconjunctivitis is other common clinical misdiagnoses of SC, especially in the spreading superficial clinical presentation, 

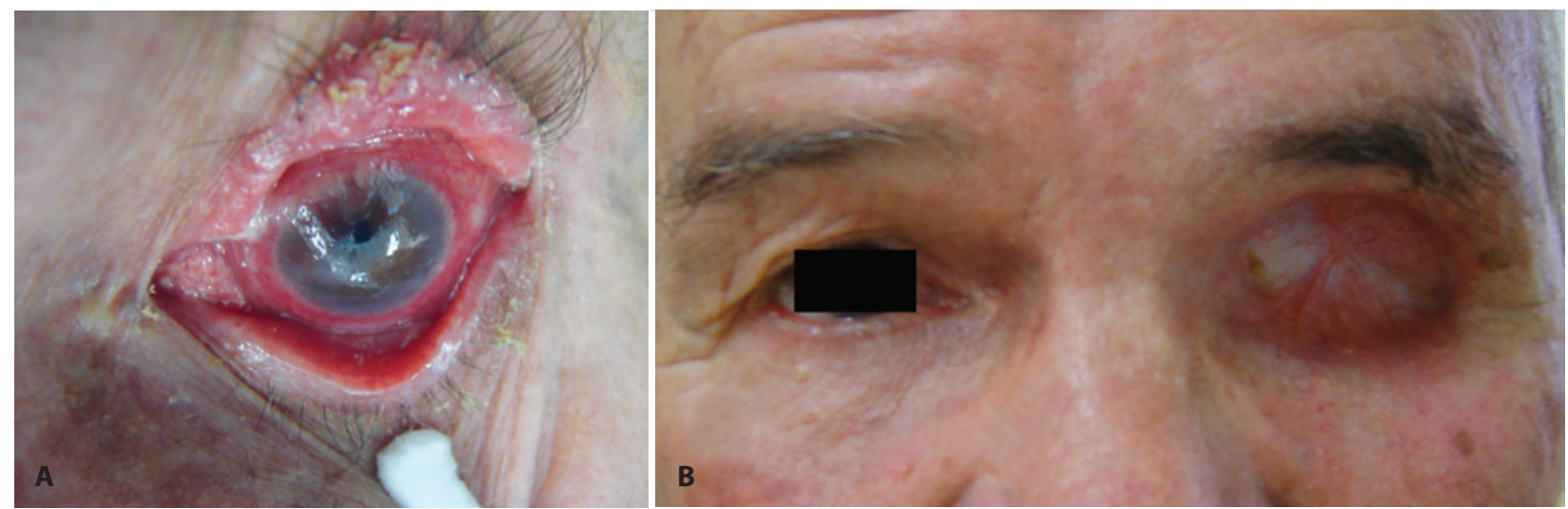

Figure 3. Patient 3: thickened and hyperemic left eyelid with difuse conjunctival hyperemia (A). Three months after orbital exenteration (B).

like seen in case 3. Dragging or recurrent cases of blepharoconjunctivitis are strong candidates for cytology impression or even biopsy, depending on clinical features ${ }^{(8)}$. Nodular SC is easier to be perceived both by patients and by physicians compared with the spreading SC. It probably also contributed to late diagnosis and worse prognosis of case 3 . The majority of SC cases affect the upper eyelid ${ }^{(2)}$, probably due to the greater concentration of meibomian glands in this region. BCC and SCC, on the other hand, usually involve the lower $\operatorname{lid}^{(2)}$. Thus, it has been suggested that any clinically malignant lesion of the upper lid should be considered SC until proven otherwise ${ }^{(4)}$.

Upper eyelids SC tend to metastasize to preauricular and parotid nodes, which represent the most common sites of metastasis. Tumors of the lower eyelid can metastasize to submandibular and cervical nodes. Death from metastasis can reach $6 \%$ of cases $^{(3)}$.

Thus, patient should be referred to an oncologist for properly systemic evaluation and follow-up, even after a successful free margin surgery. There is no specific follow-up guideline for SC in the literature. Given the rarity of SC of the eyelid, surveillance recommendations would require a thorough literature review of this topic and discussion among groups of experts. A series of 3 cases is not enough to support this, but due to similar metastizing pattern, the guideline for melanoma follow-up ${ }^{(9)}$ could probably be appropriated. It includes follow-up visit every 3 months until 2 years have passed from the diagnosis. Thereafter, follow-up is continued every 6 months for 5 years.

SC first metastasizes into regional lymph nodes, which should be followed-up carefully by palpation. Recently, it was demonstrated that sentinel node analysis may be also helpful to detect subclinical metastasis in SC, but the false-negative rate is higher than that reported for sentinel node biopsy at most other anatomic sites ${ }^{(10)}$. If the clinical examination in these follow-ups suggests tumor spreading, a chest $x$-ray, blood count, liver function tests, and liver ultrasonography should be performed ${ }^{(9)}$. Muir-Torre syndrome should be also remembered and multidisciplinary investigation is also recommended ${ }^{(1)}$.

Even with this suggested melanoma guideline follow-up, some rhetoric questions like "What is the basis for recommending ultrasound rather than CT scans, since ultrasound may miss metastatic disease?", "Based on the sites of metastases, why would imaging of the brain not be done?", "What treatment would be available for treatment of metastatic disease detected with surveillance imaging?" and "Is there evidence that early detection improves survival?" show us the necessity of developing surveillance guidelines for SC of the eyelid and other skin areas.

\section{REFERENCES}

1. Dores GM, Curtis RE, Toro JR, Devesa SS, Fraumeni JF Jr. Incidence of cutaneous sebaceous carcinoma and risk of associated neoplasms: insight into Muir-Torre syndrome. Cancer. 2008;113(12):3372-81

2. Kass LG, Hornblass A. Sebaceous carcinoma of the ocular adnexa. Surv Ophthalmol. 1989:33(6):477-90

3. Shields JA, Demirci H, Marr BP, Eagle RC Jr, Shields CL. Sebaceous carcinoma of the eyelids: personal experience with 60 cases. Ophthalmology. 2004:111(12):2151-7.

4. Khan JA, Doane JF, Grove AS Jr. Sebaceous and meibomian carcinomas of the eyelid. Recognition, diagnosis, and management. Ophthal Plast Reconstr Surg. 1991;7(1):61-6.

5. Song A, Carter KD, Syed NA, Song J, Nerad JA. Sebaceous cell carcinoma of the ocula adnexa: clinical presentations, histopathology, and outcomes. Ophthal Plast Reconstr Surg. 2008;24(3):194-200

6. Tyers AG, Collin JR, editors. Colour atlas of ophthalmic plastic surgery. $3^{\text {rd }}$ ed. London: Elsevier; 2008 .

7. Bolognia JL, Jorizzo JL, Rapini RP. Sebaceous carcinoma. In: Callen JP, Horn TD, Mancini AJ, Salasche SJ, Schaffer JV, Schwarz T, et al, editors. Dermatology. $2^{\text {nd }}$ ed. Amsterdam: Elsevier; 2008.

8. Putterman AM. Conjunctival map biopsy to determine pagetoid spread. Am J Ophthalmol. 1986;102(1):87-90

9. Finnish Medical Society Duodecim. Skin cancer. In: EBM Guidelines. Evidence-Based Medicine [Internet]. Helsinki, Finland: Wiley Interscience. John Wiley \& Sons; 2005. [cited 2010 Nov 20]. Available from: http://guideline.gov/content.aspx?f=rss\&id=24711

10. Savar A, Oellers P, Myers J, Prieto VG, Torres-Cabala C, FrankSJ, et al. Positive sentinel node in sebaceous carcinoma of the eyelid. Ophthal Plast Reconstr Surg. 2011;27(1):e4-6. 